\title{
Pharmacognosy
}

\section{Duroia saccifera: in vitro germination, friable calli and identification of $\beta$-sitosterol and stigmasterol from the active extract against Mycobacterium tuberculosis}

\author{
Stefhania Alzate Lozano ${ }^{1}$, Aline Bastos Brilhante de Sousa ${ }^{1}$, Julio Cezar de Souza ${ }^{1}$, \\ David Ribeiro da Silva ${ }^{1}$, Marcos Gabriel Maciel Salazar ${ }^{1}$, Priscila Cristina Bartolomeu Halicki ${ }^{2}$, \\ Daniela Fernandes Ramos ${ }^{2}$, Pedro Eduardo Almeida da Silva ${ }^{2}$ \& Cecilia Veronica Nunez ${ }^{1,3,4}$
}

\begin{abstract}
Duroia saccifera (Rubiaceae) occurs in the Amazon rainforest and their extracts showed antibacterial properties. To obtain greater quantities of active substances, leaf segments from in vitro D. saccifera seedlings were used as explants for calli induction; calli were multiplied via multiple subcultures, dried and extracted with hexane followed by ethyl acetate (EtOAc) and methanol (MeOH). As D. macrophylla had been reported to produce antimycobacterial substances, we assayed calli extracts against Mycobacterium tuberculosis (H37Rv strain). Calli EtOAc extract was active, with a minimal inhibitory concentration (MIC) of $\leq 25 \mu \mathrm{g} \mathrm{mL}{ }^{-1}, \mathrm{IC}_{90}$ of $19.5 \mu \mathrm{g} \mathrm{mL}{ }^{-1}$ and minimal bactericidal concentration (MBC) of $200 \mu \mathrm{g} \mathrm{mL}{ }^{-1}$. EtOAc extract was analyzed by Thin Layer Chromatography (TLC) and Nuclear Magnetic Resonance (NMR) to determine its chemical profile, and was found to be rich in terpenes. Chromatographic fractionation of the EtOAc extract yielded a mixture of two sterols, $\beta$-sitosterol and stigmasterol (in proportion of 2:1), which were identified by ${ }^{1} \mathrm{H}$ and ${ }^{13} \mathrm{C}$ NMR analysis. As far as we know, this is the first report of Duroia saccifera in vitro cell culture, antituberculosis activity of calli extract and $\beta$-sitosterol and stigmasterol isolation from in vitro plant cell culture.
\end{abstract}

Key words: antituberculosis, phytochemistry, plant tissue culture, Rubiaceae, sterols.

\begin{abstract}
Resumo
Duroia saccifera (Rubiaceae) ocorre na floresta Amazônica. Seus extratos apresentaram atividade antibacteriana. Para obter maiores quantidades de substâncias ativas, foram utilizados segmentos de folhas de plântulas in vitro de $D$. saccifera como explantes para indução de calos; os calos foram multiplicados através de múltiplos subcultivos, depois secos e extraídos com hexano, seguido por acetato de etila (AcOEt) e metanol (MeOH). Como D. macrophylla foi relatada como produtora de substâncias antimicobacterianas, os extratos de calos foram testados contra Mycobacterium tuberculosis (cepa H37Rv). O extrato AcOEt dos calos foi ativo, com uma concentração inibitória mínima (CIM) de $\leq 25 \mu \mathrm{g} \mathrm{mL}{ }^{-1}, \mathrm{IC}_{90}$ de $19,5 \mu \mathrm{g} \mathrm{mL} \mathrm{mL}^{-1} \mathrm{e}$ concentração bactericida mínima (MBC) de $200 \mu \mathrm{g} \mathrm{mL}^{-1}$. O extrato AcOEt foi analisado por cromatografia em camada delgada comparativa (CCDC) e Ressonância Magnética Nuclear (RMN) para determinar o seu perfil químico e mostrou ser rico em terpenos. O fracionamento cromatográfico do extrato AcOEt conduziu ao isolamento de uma mistura de dois esteroides, $\beta$-sitosterol e estigmasterol (na proporção de 2:1), os quais foram identificados por análises de RMN de ${ }^{1} \mathrm{H}$ e bidimensionais. Pelo levantamento bibliográfico realizado, este é o primeiro relato da cultura de células in vitro de Duroia saccifera, da atividade antituberculose do extrato de calos e do isolamento de $\beta$-sitosterol e estigmasterol da cultura de células vegetais in vitro da espécie. Palavras-chave: antituberculose, fitoquímica, cultura de tecidos vegetais, Rubiaceae, esterois.
\end{abstract}

\footnotetext{
${ }^{1}$ Instituto Nacional de Pesquisas da Amazônia - INPA, Lab. Bioprospecção e Biotecnologia, Av. André Araújo 2936, Petrópolis, 69067-375, Manaus, AM, Brazil.

${ }^{2}$ Universidade Federal do Rio Grande, FURG, Faculdade de Medicina, Núcleo de Pesquisa em Microbiologia Médica, R. General Neto s/n, 96200010, Rio Grande, RS, Brazil.

${ }^{3}$ ORCID: <https://orcid.org/0000-0003-3400-9508>

${ }^{4}$ Author for correspondence: cecilia@inpa.gov.br
} 


\section{Introduction}

Tuberculosis (TB) is a chronic contagious disease caused by Mycobacterium tuberculosis (WHO 2017). TB is one of the 10 leading causes of mortality worldwide and more than $95 \%$ of TB deaths occur in low- and middleincome countries. In recent decades, the drugs clinically available for TB treatment (rifampin and isoniazid) have become ineffective, as the causative microorganism has developed resistance, so causing an increase in the number of patients who have the disease in a resistant form (WHO 2017). This serious public health problem has led to a renewed initiative to search for novel effective drugs, including new natural plant products, which might potentially fight TB.

As part of the search for new antituberculosis substances conducted by our bioprospection research group, we had previously isolated two triterpenes and eight indole alkaloids from Duroia macrophylla that were active against $M$. tuberculosis (H37Rv strain) (Martins et al. 2013; Nunez et al. 2014).

In order to discover other plant sources, we studied the congener, Duroia saccifera (Mart. ex Roem. \& Schult.) K. Schum. (Rubiaceae). This rainforest tree occurs in Brazil, Colombia, Venezuela, and Peru (Taylor et al. 2007). In Brazil, it is popularly known as "cabeça-deurubu", "puruí-da-mata" or "puruí-grande" (Cavalcante 1974), and is present in the states of Acre, Amazonas, Pará, and Rondônia, where it occurs in unflooded ("terra firme") and adjacent seasonally-inundated forests, on both whitewater ("várzea") and black-water ("igapó") rivers (Taylor et al. 2007).

The main activities reported for extracts obtained from wild individuals of $D$. saccifera are antioxidant activity (Mesquita et al. 2015), antifungal activity against Candida glabrata, $C$. albicans (Reis et al. 2016), antibacterial activity against Salmonella enterica, Propionibacterium acnes and Enterobacter cloacae (ContrerasMejia 2017), and also antimycobacterial activity against Mycobacterium tuberculosis (Reis et al. 2016; Carrion et al. 2013).

To obtain a renewable source of $D$. saccifera material, we carried out an in vitro callus establishment protocol and phytochemical study of the ethyl acetate calli extract to isolate and identify calli-derived substances biologicallyactive against Mycobacterium tuberculosis.

\section{Material and Methods}

Plant material

To establish an in vitro cell culture fruits and seeds of Duroia saccifera were collected from wild plants growing in the Reserva Adolfo Ducke (255'46.25”S, 5958'29.69'W), Manaus, Amazonas state, Brazil, under IBAMA's collection permit number 16970-1. A voucher (number 259229) was deposited in Herbarium of Instituto Nacional de Pesquisas da AmazôniaINPA, Manaus.

\section{Germination}

A pre-disinfection of the fruit was made using a disinfectant solution of Mancozeb ${ }^{\circledR}$ $\left(2 \mathrm{~g} \mathrm{~L}^{-1}\right)$ plus streptomycin $\left(100 \mathrm{mg} \mathrm{L}^{-1}\right)$ for 30 minutes, followed by ethanol $(70 \% \mathrm{v} / \mathrm{v})$ immersion for 5 minutes. Seeds disinfection followed an ethanol $(70 \% \mathrm{v} / \mathrm{v})$ immersion for 1 minute in a laminar flow chamber, followed by an immersion in $\mathrm{NaClO}(2 \% \mathrm{v} / \mathrm{v})$ for 5 minutes, with three washes in autoclaved distilled water between the disinfecting agents.

After disinfection, seeds were inoculated onto MS medium (Murashige \& Skoog 1962) supplemented with sucrose $\left(30 \mathrm{~g} \mathrm{~L}^{-1}\right)$, agar (7 $\mathrm{g} \mathrm{L}^{-1}$ ) and $21.54 \mu \mathrm{mol} \mathrm{L}^{-1}$ of gibberellic acid $\left(\mathrm{GA}_{3}\right)$, and cultivated for 90 days, without changing medium or subcultures. The seeds were maintained in a growth room at $26 \pm 2$ ${ }^{\circ} \mathrm{C}$ and $60 \%$ average humidity, under a $16: 8 \mathrm{~h}$ photoperiod (light:dark), with a light intensity of $50 \mu \mathrm{mol}^{-2} \mathrm{~m}^{-2} \mathrm{~s}^{-1}$ given by white fluorescent lamps. After germination, seedlings were subjected to successive subcultures every 30 days.

\section{Callus induction}

Complete leaves from in vitro seedlings of D. saccifera were used as explants for callogenesis induction. They were cut at the base of the leaf blade and inoculated into sterile test tubes containing $5 \mathrm{~mL}$ MS medium (Murashige \& Skoog 1962), supplemented with sucrose (30 g $\left.\mathrm{L}^{-1}\right)$ and agar $\left(7 \mathrm{~g} \mathrm{~L}^{-1}\right)$ in a laminar flow chamber. We added 2,4-dichlorophenoxyacetic (2,4-D) $\left(17.24 \mu \mathrm{mol} \mathrm{L}^{-1}\right)$ and kinetin $\left(8.62 \mu \mathrm{mol} \mathrm{L}^{-1}\right)$ as growth regulators. Cultures were then maintained in a growth room at $26 \pm 2{ }^{\circ} \mathrm{C}$ and $60 \%$ average humidity, under a 16:8 $\mathrm{h}$ photoperiod (light:dark), with a light intensity of $50 \mu \mathrm{mol}^{-2} \mathrm{~m}^{-2} \mathrm{~s}^{-1}$ given by white fluorescent lamps. 
After 60 days in culture, induced calli were subcultured in new tubes. After 30 days they were transferred from the test tubes to glass jars with $25 \mathrm{~mL}$ of medium, and subsequently subjected to successive subcultures every 30 days in order to increase mass.

Extraction, fractionation and isolation

Duroia saccifera calli were manually removed from the culture medium and combined achieving a fresh calli total weight of 1.238 $\mathrm{kg}$. They were lyophilized (model ALPHA 1-2 LDplus, Christ) and powdered yielding $54.49 \mathrm{~g}$ (4.4\% of dry material). The lyophilized powder was then extracted first with hexane $(1 \mathrm{~g}: 10$ $\mathrm{mL}$ ), using ultrasound for $20 \mathrm{~min}$, filtered and re-extracted with hexane, repeating 4 times. Then the calli was extracted with ethyl acetate (EtOAc) by the same procedure 5 times and finally with methanol $(\mathrm{MeOH})$, also 5 times by the same procedure. All extracts (hexane, EtOAc and $\mathrm{MeOH})$ were concentrated in a rotary evaporator (model 802, Fisatom). Extracts and all fractions were analyzed by Thin Layer Chromatography (TLC) (Merck) of silica with $\mathrm{UV}_{254}$ on aluminum support, eluted with suitable systems, and revealed under UV light $(\lambda=254$ and $365 \mathrm{~nm})$, sulfuric $p$-anisaldehyde, $\mathrm{Ce}\left(\mathrm{SO}_{4}\right)_{2}, \mathrm{FeCl}_{3}$, and Dragendorff's reagent.

The crude EtOAc extract (1.7 g) was subjected to chromatographic column CC (33.5 $\times 3 \mathrm{~cm})$ fractionation with silica gel $\left(\mathrm{SiO}_{2}\right)(86.8$ g), eluted with a gradient solvent system of DCM/ $\mathrm{MeOH}(95: 5,97: 3,9: 1,85: 15,8: 2,7: 3,6: 4,1: 1)$ and $\mathrm{MeOH} 100 \%$, yielding 98 fractions. Fractions $(25 \mathrm{~mL})$ were collected and grouped by TLC analysis. Fractions 5-11 (126 mg) were again fractionated in $\mathrm{SiO}_{2}(12.6 \mathrm{mg}) \mathrm{CC}(25 \times 1.5 \mathrm{~cm})$ and eluted with a gradient of DCM/Acetone (98:2, 95:5, 9:1, 85:15, 8:2, 7:3, 1:1) and 100\% Acetone, yielding 57 fractions. A white amorphous powder was formed in the fraction 7-9 and was named compound 1 ( $7 \mathrm{mg})$.

\section{Structural characterization}

In order to determine the chemical structure, the fraction was dissolved in $\mathrm{CDCl}_{3}$ and analyzed by Nuclear Magnetic Resonance (NMR) obtained with a Fourier 300 spectrometer (Bruker), operating at 300 for ${ }^{1} \mathrm{H}$ and $75 \mathrm{MHz}$ for ${ }^{13} \mathrm{C}$ nuclei, respectively. All NMR shifts were expressed in ppm related to TMS signal at $0.00 \mathrm{ppm}$ as internal reference.
Antituberculosis activity

The resazurin microtiter assay (REMA) was performed to test extract activity against Mycobacterium tuberculosis, at the Medical Microbiology Research Nucleus (NUPEMM), Federal University of Rio Grande (FURG). Extracts were tested at the initial concentration of $400 \mu \mathrm{g} \mathrm{mL}^{-1}$. In each experiment, $100 \mu \mathrm{L}$ of extracts, serially diluted in Middlebrook $7 \mathrm{H} 9$ medium supplemented with 10\% OADC (oleic acid, albumin, dextrose and catalase) and $100 \mu \mathrm{L}$ of the inoculum, were incubated at $37^{\circ} \mathrm{C}$ for 7 days in a 96 well plate. Following incubation, $30 \mu \mathrm{L}$ of resazurin $(0.02 \%)$ was added in each well and further incubated for two days at $37^{\circ} \mathrm{C}$. Biological activity was assayed based on the change of color from blue to pink, when oxidation of the reagent occurs due to bacterial growth. Rifampicin and isoniazid drugs were used as positive controls (Palomino et al. 2002).

\section{Results}

\section{Germination}

Of the 108 initial seeds, $24 \%$ developed fungus contamination and $25 \%$ did not germinate. After 50 days of cultivation, the emergence of the radicle was observed in the remainder. The hypocotyl and radicle elongation occurred after 60 days. Secondary root formation occurred after 72 days and fully developed cotyledons after 82 days. After 90 days, $50 \%$ of the seedlings were fully formed (Fig. 1a-f).

\section{Callus induction}

Callus formation began after 15 days, when cell growth occurred in the central part of the leaf and at the end of leaf segments. After 60 days, the explants were completely transformed into callus and were then subcultured in new tubes, even though they still had zones of green coloration, which indicated cell masses with some degree of differentiation. After 90 days, they had a friable appearance, when the surface of the calli took on a smoothly nodulated appearance, and coloration ranged between whitish and yellowish (Fig. 2a-f).

Extraction, fractionation and isolation

TLC analysis of EtOAc extract obtained from D. saccifera calli indicated a high concentration of terpenes when the plates were sprayed with $\mathrm{Ce}\left(\mathrm{SO}_{4}\right)_{2}$ and sulfuric anisaldehyde. When revealed with UV light $(\lambda=365 \mathrm{~nm})$ fluorescence, 

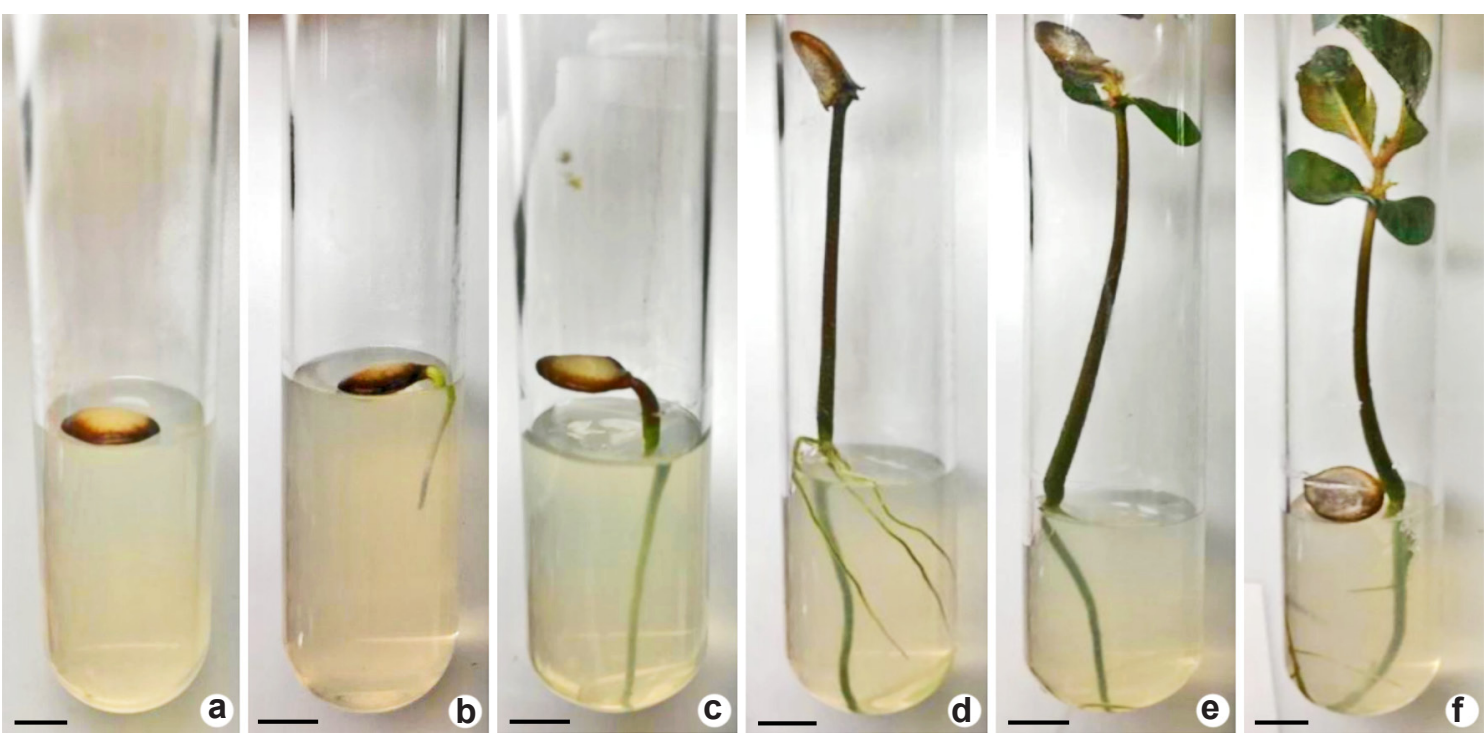

Figure 1 - a-f. In vitro germination of $D$. saccifera - a. seed; b. emerging radicle; c. hypocotyl and radicle elongation; d. secondary root formation; e. emergence of cotyledons; f. extension of leaf primordium. Scale bar: $0.5 \mathrm{~cm}$.

the plates indicated the presence of molecules with conjugated double bonds. When the plates were sprayed with $\mathrm{FeCl}_{3}$ and Dragendorff's reagent no spots were visible, which indicated the absence or very low concentrations of phenolic substances and alkaloids.

\section{Structural characterization}

${ }^{1} \mathrm{H}-\mathrm{NMR}$ data for fraction 7-9 showed the presence of several signals in the shielded region between $\delta 0.6(\mathrm{~s})$ and $1.25(\mathrm{~s})$, characteristic of methyl hydrogens; and two signals at $\delta 5.35$
$(4 \mathrm{H}, \mathrm{d}, J=5.22 \mathrm{~Hz})$ and $3.53(4 \mathrm{H}$, sept, $J=5$ $\mathrm{Hz}$ ) suggesting the presence of C- 6 and C-3 of skeletal hydrogens of a stigmastane steroid. Two resonances at $\delta 5.15(1 \mathrm{H}, \mathrm{dd}, J=15.18,8.47 \mathrm{~Hz})$ and $\delta 5.01(1 \mathrm{H}, \mathrm{dd}, J=15.18,8.47 \mathrm{~Hz})$ suggested the presence of stigmasterol, but the integrals of these signals showed values half of the previous signals, indicating a mixture of two steroids, with $\beta$-sitosterol present in greater quantity $(2: 1)$.

The ${ }^{13} \mathrm{C}$-RMN data showed signals at $\delta$ 140.75 and 121.74 , common for both steroids, with signals in $\delta 138.24$ and 129.25 being less
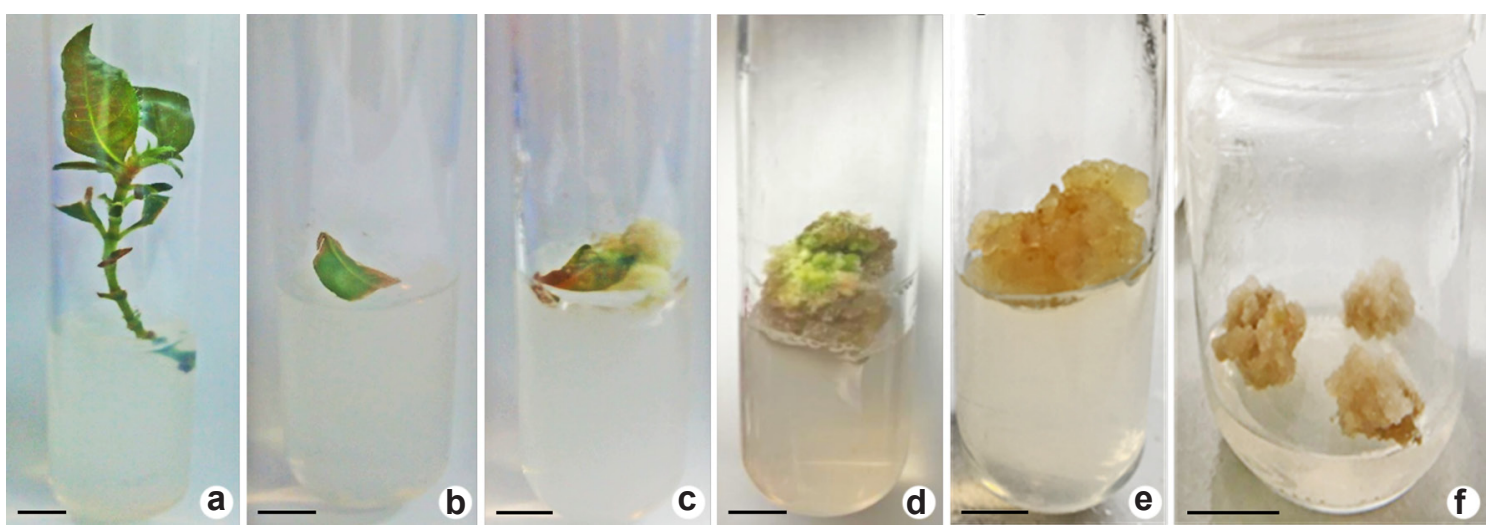

Figure 2 - a-f. Callogenesis induction of D. saccifera - a. in vitro seedlings; b. leaf segments used as explants; c. cell growth in the central part of the leaf and at the end of leaf segments; d. complete transformation of the explant into callus; e. friable appearance; f. calli subcultured in jars. Scale bar: a-e. $0.5 \mathrm{~cm}$; f. $2 \mathrm{~cm}$. 
intense, these being a characteristic signals of stigmasterol. The HSQC spectrum showed the following correlations for the observed signals that made it possible to distinguish steroids: $\delta$ 5.35 with $121.74, \delta 5.15$ with $138.34, \delta 5.01$ with 129.25 , and $\delta 3.53$ with 71.81 .
It was also possible to observe steroid methyl singlets in the ${ }^{1} \mathrm{H}-\mathrm{RMN}$ spectrum, which could be correlated with each carbon atom by HSQC experiment analysis. For $\beta$-sitosterol, the correlations of these methyl groups were: $\delta 0.68$ with $11.85, \delta 0.80$ with $18.93, \delta 0.82$ with 19.73 ,

Table $1-{ }^{1} \mathrm{H}$ and ${ }^{13} \mathrm{C}$ NMR chemical displacements observed for $\beta$-sitosterol and stigmasterol $\left(300 \mathrm{MHz} \mathrm{CDCl}_{3}\right)$.

\begin{tabular}{|c|c|c|c|c|c|c|}
\hline \multirow{2}{*}{ Position } & \multicolumn{3}{|c|}{$\beta$-Sitosterol } & \multicolumn{3}{|c|}{ Stigmasterol } \\
\hline & ${ }^{13} \mathrm{C}$ & ${ }^{1} \mathbf{H}$ & ${ }^{13} \mathrm{C}$ Literature ${ }^{1}$ & ${ }^{13} \mathrm{C}$ & ${ }^{1} \mathbf{H}$ & ${ }^{13} \mathrm{C}$ Literature ${ }^{2}$ \\
\hline 1 & 37.24 & $1.80,1.05$ & 37.3 & 37.24 & & 37.31 \\
\hline 2 & 31.89 & $1.82,1.52$ & 31.6 & 32.41 & & 31.72 \\
\hline 3 & 71.81 & 3.53 & 71.8 & 71.81 & 3.53 & 71.85 \\
\hline 4 & 42.29 & $2.28,2.22$ & 42.3 & 42.29 & & 42.37 \\
\hline 5 & 140.75 & - & 140.8 & 140.75 & & 141.01 \\
\hline 6 & 121.74 & 5.35 & 121.7 & 121.74 & 5.35 & 121.73 \\
\hline 7 & 31.89 & $1.95,1.52$ & 32.1 & 31.65 & & 31.72 \\
\hline 8 & 31.89 & 1.53 & 32.1 & 31.65 & & 31.79 \\
\hline 9 & 50.1 & 0.91 & 50.2 & 50.1 & & 50.19 \\
\hline 10 & 36.49 & - & 36.5 & 36.15 & & 36.17 \\
\hline 11 & 21.08 & 1.46 & 21.1 & 21.22 & & 21.11 \\
\hline 12 & 39.76 & $1.99,1.14$ & 39.8 & 39.76 & & 40.10 \\
\hline 13 & 42.3 & - & 42.3 & 42.3 & & 42.41 \\
\hline 14 & 56.85 & 0.87 & 56.8 & 56.75 & & 56.12 \\
\hline 15 & 24.30 & $1.55,1.03$ & 24.3 & 24.30 & & 23.12 \\
\hline 16 & 28.94 & $1.82,1.24$ & 28.3 & 29.35 & & 29.72 \\
\hline 17 & 56.02 & 1.08 & 56.1 & 55.96 & & 56.12 \\
\hline 18 & 11.85 & 0.68 & 12.0 & 11.97 & & 12.01 \\
\hline 19 & 19.40 & 1.01 & 19.1 & 19.86 & & 19.42 \\
\hline 20 & 35.89 & 1.34 & 36.2 & 39.74 & & 41.10 \\
\hline 21 & 18.77 & 0.94 & 18.8 & 20.53 & & 21.10 \\
\hline 22 & 33.92 & $1.29,0.99$ & 34.0 & 138.34 & 5.15 & 138.00 \\
\hline 23 & 26.00 & 1.15 & 26.2 & 129.25 & 5.01 & 128.95 \\
\hline 24 & 45.80 & 0.90 & 45.2 & 51.23 & & 50.15 \\
\hline 25 & 29.1 & 1.64 & 29.2 & 29.70 & & 31.72 \\
\hline 26 & 19.01 & 0.80 & 18.9 & 21.86 & & 21.30 \\
\hline 27 & 19.84 & 0.82 & 19.1 & 18.70 & & 19.06 \\
\hline 28 & 23.03 & 1.23 & 23.1 & 25.4 & & 25.38 \\
\hline 29 & 11.85 & 0.85 & 11.9 & 11.97 & & 12.28 \\
\hline
\end{tabular}

Assignments made on the basis of COSY, HMQC and HMBC correlations; chemical displacements are in $\delta$ (ppm). ${ }^{1} \mathrm{Kovganko}$ et al. 1999 (360 MHz, CDCl3); ${ }^{2}$ Khatun et al. 2012 (400 MHz, CDCl3). 
$\delta 0.83$ with $18.32, \delta 0.85$ with $11.86, \delta 1.01$ with 19.13 , while the correlations for stigmasterol were: $\delta 0.70$ with $11.85, \delta 0.80$ with $18.93, \delta 0.83$ with $20.62, \delta 0.85$ with $20.60, \delta 1.03$ with 19.13 , plus $\delta 1.04$ with 21.55 (Tab. 1).

\section{Anti-tuberculosis activity}

The EtOAc extract showed activity against M. tuberculosis (H37Rv strain), exhibiting MIC $\leq 25 \mu \mathrm{g} \mathrm{mL}^{-1}$ and Minimum Bactericidal Concentration (MBC) of $200 \mu \mathrm{g} \mathrm{mL}{ }^{-1}$. The $\mathrm{MeOH}$ extract showed no determined activity (Tab. 2).

\section{Discussion}

Previous studies on wild collected plants of D. macrophylla and D. saccifera have found biological activity against three $M$. tuberculosis strains: one pan-susceptible H37Rv (ATCC 27294) and two mono resistant strains, INH (ATCC 35822) and RIF (ATCC 35338) where leaves and branches crude extracts showed MIC values varied from 50 to $200 \mu \mathrm{g} \mathrm{mL} \mathrm{mL}^{-1}$ (Reis et al. 2016; Carrion et al. 2013). A second study reported the isolation of the triterpenes oleanoic and ursolic acid active against $M$. tuberculosis strain (MIC $200 \mu \mathrm{g} \mathrm{mL}^{-1}$ ) from D. macrophylla extracts (Martins et al. 2013).

Several other studies have shown terpenes to be responsible for antimycobacterial activity (Seidel \& Taylor 2004; Aguiar et al. 2005; Higuchi et al. 2008; Subramaniam et al. 2014; Evina et al. 2017; Suja et al. 2017). Their high lipophilicity is probably the main factor that allows their penetration through the mycobacterial cell wall (Higuchi et al. 2008).

Reviews of the numerous plant species and active compounds showing antimycobacterial activity indicate $\beta$-sitosterol and stigmasterol to be important phytochemical components in this process (Chinsembu 2016; Tiwari et al. 2019). Suja (2017) reported growth inhibition activity of M. tuberculosis with a MIC of 25 and $100 \mu \mathrm{g} \mathrm{mL}^{-1}$ for $\beta$-sitosterol and stigmasterol, respectively. A study conducted by Saludes et al. (2002) reported the $\beta$-sitosterol and stigmasterol MICs to be 128 and $32 \mu \mathrm{g} \mathrm{mL}^{-1}$, respectively. In the current study, we found a mixture of both substances which have similar structures, differing only in the position of an extra double bound (present in stigmasterol), which complicates their separation (Xu et al. 2005; Pierre \& Moses 2015). This, and the small quantity of isolated mixture, meant it was not possible try to purify them further.

\section{Conclusions}

In this study, for the first time, we report in vitro germination, callus induction, and inhibitory activity, of EtOAc extract of $D$. saccifera calli against $M$. tuberculosis. $\beta$-sitosterol and stigmasterol were obtained for the first time from in vitro callus culture of this species. In vitro $D$. saccifera cultures have a broad potential for supply of active secondary metabolites, mainly terpenes. Fractionation of the EtOAc extract should be continued in order to isolate, identify and assay other possible active substances that could lead to the discovery of new anti-tuberculosis drugs.

\section{Acknowledgements}

The authors wish to thank the Brazilian Research Agencies: CNPq (CT-Agro/CNPq 562892/2010-9, PPBio/CNPq 457472/20120, CT-Amazônia/CNPq - 405804/2013-0 and productivity 309654/2016-5) and CAPES (ProAmazônia/CAPES - 23038.000738/2013-78) for the financial support and scholarships. To Adrian A. Barnett for the English revision.

Table 2 - Minimum inhibitory concentration (MIC), Inhibitory concentration of $90 \%$ of bacterial growth (IC ${ }_{90}$ ) and Minimum Bactericidal Concentration (MBC) of callus extracts of Duroia saccifera against Mycobacterium tuberculosis (H37Rv).

\begin{tabular}{cccc}
\hline Extract / control & $\mathbf{M I C}\left(\boldsymbol{\mu g} \mathbf{~ m L}^{-1}\right)$ & $\mathbf{I C}_{\mathbf{9 0}}\left(\boldsymbol{\mu g} \mathbf{~ m L}^{-1}\right)$ & $\mathbf{M B C}_{\left(\boldsymbol{\mu g} \mathbf{~ m L}^{-1}\right)}$ \\
\hline EtOAc & $\leq 25$ & 19.5 & 200 \\
$\mathrm{MeOH}$ & $>400$ & $>400$ & $>400$ \\
$\mathrm{RMP}$ & $\leq 0.01$ & nd & nd \\
$\mathrm{INH}$ & 0.03 & nd & nd \\
\hline
\end{tabular}

EtOAc $=$ ethyl acetate $\mathrm{MeOH}=$ methanol; $\mathrm{RMP}=$ rifampicin; $\mathrm{INH}=$ isoniazid; $\mathrm{nd}=$ not determined. Extract with $\mathrm{MIC}>400 \mu \mathrm{g} \mathrm{mL}^{-1}$ were considered inactive. 


\section{References}

Aguiar RM, David JP \& David JM (2005) Unusual naphthoquinones, catechin and triterpene from Byrsonima microphylla. Phytochemistry 66: 23882392.

Cavalcante PB (1974) Frutas comestíveis da Amazônia. Repositório Museu Paraense Emílio Goeldi. Vol. 27. Publicações avulsas, Belém. 80p.

Carrion LL, Ramos DF, Martins D, Osório MIC, Cursino LD, Mesquita DWO \& Dasilva PEA (2013) Antimycobacterial activity of Brazilian Amazon plants extracts. International Journal of Phytomedicine 5: 479.

Chinsembu KC (2016) Tuberculosis and nature's pharmacy of putative anti-tuberculosis agents. Acta Tropica 153: 46-56.

Contreras-Mejia JA (2017) Estudo fitoquímico do extrato hexânico das folhas de Duroia saccifera (Mart. ex Roem \& Schult.) Hook. F ex Schumann (Rubiaceae). Dissertação de Mestrado. Universidade Federal do Amazonas, Manaus. 75p.

Evina JN, Bikobo DSN, Zintchem AAA, Nyemeck II, Mbabi N, Ndedi EDFM \& Koert U (2017) In vitro antitubercular activity of extract and constituents from the stem bark of Disthemonanthus benthamianus. Revista Brasileira de Farmacognosia 27: 739-743.

Higuchi CT, Pavan FR, Leite CQF, Sannomiya M, Vilegas W, Leite SRA, Sacramento LVS \& Sato DN (2008). Triterpenes and antitubercular activity of Byrsonima crassa. Química Nova 31: 1719-1721.

Khatun M, Billah M \& Quader MA (2012). Sterols and sterol glucoside from Phyllanthus species. Dhaka University Journal of Science 60: 5-10.

Kovganko NV, Kashkan ZN, Borisov EV \& Batura EV (1999). ${ }^{13} \mathrm{C}$ NMR spectra of $\beta$-sitosterol derivatives with oxidized rings A and B. Chemistry of Natural Compounds 35: 646-649.

Martins D, Carrion LL, Ramos DF, Salomé KS, Silva PEA, Barison A \& Nunez CV (2013) Triterpenes and the antimycobacterial activity of Duroia macrophylla Huber (Rubiaceae). BioMed Research International 1: $1-7$.

Mesquita DWO, Mesquita ASS, Cursino LMC, Souza ES, Oliveira AC, Pinheiro CC, Novaes JAP, Oliveira JAA \& Nunez CV (2015) Atividades biológicas de espécies amazônicas de Rubiaceae. Revista Brasileira de Plantas Medicinais 17: 604-613.

Murashige T \& Skoog F (1962) A revised medium for rapid growth and bioassays with tobacco tissue cultures. Physiologia Plantarum 15: 473-497.

Nunez CV, Martins D, Ramos DF \& Silva PEA (2014) Uso de composto, método ex-vivo, processo e extrato purificado. Instituição de registro: INPI Instituto Nacional da Propriedade Industrial. Brasil. Patente: Privilégio de Inovação. Número do registro: BR1020140308636. Available at $<$ https:/gru.inpi.
gov.br/pePI/servlet/PatenteServletController?Actio $\mathrm{n}=$ detail\&CodPedido $=1008400 \&$ SearchParamete r=BR1020140308636\%20\%20\%20\%20\%20\%20 $\&$ Resumo $=\&$ Titulo $=>$. Access on 07 April 2020.

Palomino JC, Martin A, Camacho M, Guerra H, Swings J \& Portaels F (2002) Resazurin microtiter assay plate: simple and inexpensive method for detection of drug resistance in Mycobacterium tuberculosis. Antimicrobial Agents and Chemotherapy 46: 27202722.

Pierre LL \& Moses MN (2015) Isolation and characterisation of stigmasterol and $\beta$-sitosterol from Odontonema strictum (Acanthaceae). Journal of Innovations in Pharmaceutical and Biological Sciences 2: 88-96.

Reis AJ, Carrion LL, Rodrigues K, Fenalti JM, MataSantos T, Scaini CJ, Martins D, Mesquita DWO, Mesquita ASS, Nunez CV, Silva PEA \& Ramos DF (2016) Avaliação das atividades antifúngica, antimicobacteriana e larvicida de Duroia macrophylla e D. saccifera. Revista de Epidemiologia e Controle de Infecção 1: 108-124.

Saludes JP, Garson MJ, Franzblau SG \& Aguinaldo AM (2002) Antitubercular constituents from the hexane fraction of Morinda citrifolia Linn. (Rubiaceae). Phytotherapy Research 16: 883-685.

Seidel V \& Taylor PW (2004) In vitro activity of extracts and constituents of Pelagonium against rapidly growing mycobacteria. International Journal of Antimicrobial Agents 23: 613-619.

Subramaniam S, Keerthiraja M \& Sivassubramanian A (2014) Synergistic antibacterial action of $\beta$-sitosterolD-glucopyranoside isolated from Demostachya bipinnata leaves with antibiotics against common human pathogens. Revista Brasileira de Farmacognosia 24: 44-50.

Suja KP, Jose L, Lakshmanan D, Vidya AG, Reshmi NRJ \& Kumar RA (2017) Isolation and characterization of antimycobacterial compounds from fruits of Aegle marmelos (L.) Correa. The Journal of Communicable Diseases 49: 32-38.

Taylor CM, Campos MT \& Zappi D (2007) Flora da reserva Ducke, Amazonas, Brasil: Rubiaceae. Rodriguésia 58: 549-616.

Tiwari B, Shailajan S, Menon S \& Kulkarni S (2019) Tuberculosis: history, epidemiology, antitubercular drugs and plant-based alternatives. Indian Journal of Pharmaceutical Sciences 81: 200-210.

WHO - World Health Organization (2017) Global tuberculosis report. World Health Organization, Geneva. 249p.

Xu WL, Huang YB, Qian JH, Sha O \& Wang YQ (2005) Separation and purification of stigmasterol and $\beta$-sitosterol from phytosterol mixtures by solvent crystallization method. Separation and purification technology 41: 173-178.

Area Editor: Dr. Leopoldo Baratto

Received in August 07, 2019. Accepted in December 15, 2019.

\section{(cc)} This is an open-access article distributed under the terms of the Creative Commons Attribution License. 